\title{
Evaporative cooling and cutaneous surface temperature of Holstein cows in tropical conditions ${ }^{1}$
}

\author{
Roberto Gomes da Silva², Alex Sandro Campos Maia ${ }^{3}$
}

\footnotetext{
1 Projeto realizado com recursos do CNPq

2 Departmento de Zootecnia, Universidade Federal Rural do Semi-Árido, Mossoró, RN, Brazil.

${ }^{3}$ Departmento de Zootecnia, Universidade Estadual Paulista, Jaboticabal, SP, Brazil.
}

\begin{abstract}
The effects of skin temperature $\left(T_{\mathrm{S}}\right)$ on the rate of heat loss by cutaneous evaporation $\left(E_{\mathrm{S}}\right)$ in Holstein cows chronically exposed to sun, considering hair coat colour were studied. Sixteen purebred cows were measured for $E_{\mathrm{S}}$ and $T_{\mathrm{S}}$ at 01:00 p.m. after 6 hours of exposure to sun, on three body regions (flank, neck and gluteus) and considering dark and white spots separately. Sweating rate $(S)$ and $E_{S}$ were measured by means of a ventilated capsule. Black skin areas presented mean $S\left(138.9 \pm 8.5 \mathrm{gm}^{-2} \mathrm{~h}^{-1}\right)$, $E_{\mathrm{S}}\left(93.3 \pm 5.7 \mathrm{Wm}^{-2}\right)$, and $T_{\mathrm{S}}\left(33.1 \pm 0.2^{\circ} \mathrm{C}\right)$ higher than those in the white areas $\left(109.5 \pm 9.7 \mathrm{gm}^{-2} \mathrm{~h}^{-1}\right), 73.6 \pm 6.5 \mathrm{Wm}^{-2} \mathrm{and}$ $32.6 \pm 0.2^{\circ} \mathrm{C}$, respectively). There is an exponential relationship among cutaneous temperature and cutaneous evaporation, which can be represented by the equation: $E_{\mathrm{S}}=31.5+\exp \left\{\left(T_{\mathrm{S}}-27.9\right) / 2.19115\right\}$, with coefficient of determination $r^{2}=0.68$. Cutaneous evaporative heat loss remains almost constant around $48 \mathrm{Wm}^{-2}$ until $T_{\mathrm{S}}$ reaches nearly $31^{\circ} \mathrm{C}$.
\end{abstract}

Key Words: cutaneous evaporation, cutaneous temperature, Holstein cows

\section{Resfriamento evaporativo e temperatura cutânea de vacas Holandesas em ambiente tropical}

RESUMO - Foram estudados os efeitos da temperatura cutânea $\left(T_{\mathrm{s}}\right)$ sobre a taxa de termólise por evaporação cutânea $\left(E_{s}\right)$ de vacas Holandesas cronicamente expostas ao sol, considerando a pigmentação do pelame. Dezesseis vacas puras de origem foram medidas quanto à evaporação e à temperatura cutâneas às 13 h, após 6 horas de exposição ao sol, no mesmo local (flanco, pescoço e glúteo) e considerando separadamente as malhas negras e as brancas. A evaporação cutânea foi medida por meio de cápsula ventilada. Nas áreas negras a taxa de sudação $\left(138,9 \pm 8,5 \mathrm{~g} \cdot \mathrm{m}^{-2} \cdot \mathrm{h}^{-1}\right)$, a taxa de termólise por evaporação cutânea $\left(93,3 \pm 5,7 \mathrm{~W} \cdot \mathrm{m}^{-2}\right)$ e a temperatura da superfície cutânea $\left(33,1 \pm 0,2^{\circ} \mathrm{C}\right)$ foram maiores que nas áreas brancas $\left(109,5 \pm 9,7 \mathrm{~g} \cdot \mathrm{m}^{-2} \cdot \mathrm{h}^{-1}, 73,6 \pm 6,5 \mathrm{~W} \cdot \mathrm{m}^{-2}\right.$ e $32,6 \pm 0,2^{\circ} \mathrm{C}$, respectivamente). Há uma relação exponencial entre evaporação e temperatura cutâneas, que pode ser representada pela equação $E_{\mathrm{s}}=31,5+3,67 \exp \left\{\left(T_{\mathrm{s}}-27,9\right) / 2,19115\right\}$, com coeficiente de determinação $r^{2}=0,68$. A taxa de termólise por evaporação cutânea permanece quase constante (cerca de $48 \mathrm{~W} . \mathrm{m}^{-2}$ ) até que a temperatura cutânea atinge aproximadamente $31^{\circ} \mathrm{C}$.

Palavras-chave: evaporação cutânea, temperatura cutânea, vacas Holandesas

\section{Introduction}

Heat losses by convection and by long-wave radiation depend on the temperature difference between the surface of the animal and its environment. However, in tropical regions, this difference is small and often negative because elimination of latent heat depends on the vapour pressure differential instead of the temperature differential. Therefore, thermal comfort of an animal in those regions depends largely on its ability to dissipate excess of body heat by evaporative cooling either from cutaneous and respiratory surfaces (McLean, 1963b; Gatenby, 1980; Gebremedhin et al., 1981;
Gebremedhin \& Wu, 2001, 2002; Maia et al., 2005). Respiratory evaporation rate is rather smaller than the cutaneous one.

Although some amount of water always moves through the skin by diffusion, most of the evaporated water comes only from the sweat glands. Many papers have been published on the sweating ability of cattle, based on the measurement of the sweating rate (Schleger \& Turner, 1965; Allen et al., 1970; Schleger \& Bean, 1971; Amakiri \& Onwuka, 1980; Finch et al., 1982; Silva et al., 1988). Direct determination of the evaporation from the skin surface by means of ventilated capsules has also been used (McLean, 1963a.; Gatenby, 1980; Maia et al., 2005). 
However, those methods are hardly used for field research in which great numbers of animals are involved, for example in genetic surveys. Therefore, indirect methods of evaluation of the cutaneous evaporation rate would be interesting. The results of some papers (Allen, 1962; Isabirye \& Robertshaw, 1972; Finch et al., 1982) suggested a relationship between sweating rate and skin temperature. Gatenby (1986) proposed an exponential function relating both of these traits, based on measurements made with a ventilated capsule.

The objective of this study was to investigate the relationship of the skin temperature on the cutaneous evaporation rate of Holstein cattle bred in a tropical region.

\section{Material and Methods}

Sixteen purebred Holstein cows from a herd in Jaboticabal, SP, Brazil (21ํ15'22" S, 48ํ18'58" W, 595 m altitude) were used for the study. The herd was managed on open pasture, receiving silage ad libitum twice a day in the milking parlour; the cows remained in the field exposed to sun between the milkings (5:00 a.m. and 1:00 p.m., respectively). The observations on the selected cows were made just after the second milking (1:00 p.m.), one cow being measured at a time under the shade, while the rest of the cows remained outside the stall exposed to sun.

Cutaneous evaporation was measured by means of a ventilated capsule designed by Maia et al. (2005), similar to that used by McLean (1963a) and made of a section of PVC tubing with $7 \mathrm{~cm}$ in length and $9.6 \mathrm{~cm}$ in diameter. The air within the capsule was aspirated by a vacuum pump and passed through a gas analyser (Li-Cor, mod. Li-6262), in order to determine the vapour pressure of the air leaving the capsule; at short intervals the vapour pressure of the air entering the capsule was also measured in the same manner. The capsule was set upon the undisturbed hair coat, which was less than $3 \mathrm{~mm}$ deep in all of the animals. The measurements were done weekly on the central area of the flank of each animal for a time varying from five to ten minutes each. The animals were measured several times each, but because of the management routines, the numbers of repetitions were different. It was made 20 observations per animal on the average.

Because the sweat produced is completely evaporated from the skin surface of a cow, sweating rate can be given as the product of the air flow through the capsule $\left(f_{\text {cap }}, \mathrm{m}^{3} \cdot \mathrm{s}^{-1}\right)$ by the difference between the absolute humidity of the air entering the capsule $\left(\Psi_{\mathrm{atm}}, \mathrm{g} \cdot \mathrm{m}^{-3}\right)$ and that of the leaving air $\left(\Psi_{\text {cap }}\right.$, g. $\left.\mathrm{m}^{-3}\right)$, divided by the area of skin which was encircled by the capsule $\left(A_{\text {cap }}, \mathrm{m}^{2}\right)$ :
$S=\frac{3600 f_{\text {cap }}\left(\Psi_{\text {cap }}-\Psi_{\text {atm }}\right)}{A_{\text {cap }}} \mathrm{g} \cdot \mathrm{m}^{-2} \cdot \mathrm{h}^{-1}$

The rate of heat loss by cutaneous evaporation was obtained by multiplying sweating rate by the heat of vaporisation of water $\left(\lambda, \mathrm{J}^{\mathrm{g}} \mathrm{g}^{-1}\right)$ :

$E_{\mathrm{s}}=\frac{S \lambda}{3600} \mathrm{~W} \cdot \mathrm{m}^{-2}$

Skin surface temperature $\left(T_{\mathrm{s}}\right)$ was taken just before the capsule was set on the place, by using a precision temperature probe (Rynger, mod. ST) which was inserted under the hair coat. An infra-red thermometer (Horiba, mod.IT-330), adjusted for an emissivity of 0.98 , was used to determine the hair coat surface temperature for comparative purposes. As it was expected, there were virtually no differences between the temperature of the skin and that of the hair-coat surface because the haircoat was very thin $(\leq 3 \mathrm{~mm})$, dense and well settled in all of the animals, as it is generally observed in European cattle bred under tropical conditions (Silva et al., 1988; Pinheiro \& Silva, 1998, 2000). At the same time, rectal temperature $\left(T_{\mathrm{r}}\right)$ and respiratory rate $(R)$ were recorded in the cows, together with the following environmental variables: black globe temperature $\left(T_{\mathrm{g}}\right)$, air temperature $\left(T_{\mathrm{a}}\right)$, air vapour pressure $\left(P_{\mathrm{v}}\right)$ and wind speed $(W)$. The black globe was a standard one, with $15 \mathrm{~cm}$ diameter and placed $90 \mathrm{~cm}$ above the ground near the animals; dry and wet bulb temperatures were measured with a sling psychrometer under the shade, $1.2 \mathrm{~m}$ above ground; wind speed was measured near the black globe, by using a digital anemometer (Sper Scientific). Air vapour pressure was determined directly by the gas analyser. The data were analysed by the least squares method (Harvey 1960), and by non-linear regression methods (Sokal \& Rohlf, 1995). The following mathematical model was considered in the analysis of variance for $E_{\mathrm{s}}$ and $T_{\mathrm{s}}$ :

$y_{i j k}=\mu+a_{i}+c_{j}+\varepsilon_{i j k}$

where $y_{\mathrm{ijk}}=$ the $\mathrm{k}^{\text {th }}$ observation on the $\mathrm{j}^{\mathrm{th}}$ coat colour of the body of the $\mathrm{i}^{\text {th }}$ cow; $a_{\mathrm{i}}=$ the effect of the $\mathrm{i}^{\text {th }} \operatorname{cow}(\mathrm{i}=1, \ldots, 16)$ and $c_{\mathrm{j}}=$ the effect of the $\mathrm{j}^{\text {th }}$ coat $\operatorname{colour}(\mathrm{j}=1,2) ; \mu$ and $\varepsilon_{\mathrm{ijk}}=$ the overall mean and the error term, respectively.

\section{Results and Discussion}

Environmental data averages during the observations, together with their standard errors and observed ranges, were the following: air temperature $\left({ }^{\circ} \mathrm{C}\right): 23.3 \pm 0.4(12-35)$; black globe temperature $\left({ }^{\circ} \mathrm{C}\right): 27.3 \pm 0.5(12.5-46)$; partial vapour pressure $(\mathrm{kPa}): 1.69 \pm 0.03(0.86-4.74)$ and wind speed $\left(\mathrm{ms}^{-1}\right): 0.55 \pm 0.06(0-5)$. 
Cows tend to behave individually with respect to the exposure of the body to the sun and the wind, thus affecting $T_{\mathbf{s}}$. As for $S$, it is expected a variation caused by genetic differences (Silva et al., 1988). Variation on $E_{\mathrm{s}}$ values depends on those of $S$.

The mean values of the traits differed significantly between coat colours, notwithstanding the non-significance of this effect in the variance analyses (Table 2).

The average $T_{\mathrm{s}}$ of the black coat $\left(33.2 \pm 0.2^{\circ} \mathrm{C}\right)$ differed significantly $(\mathrm{P}<0.05)$ from that observed in the white areas $\left(32.6 \pm 0.2^{\circ} \mathrm{C}\right)$ which was an expected result inasmuch as black coats of Holstein cattle present a very low reflectance to the solar radiation: 0.04 for the wavelength range 300 to $850 \mathrm{~nm}$ whereas the white coats have a reflectance of 0.60 (Silva et al., 2003). Those measurements were made in the same animals under the same conditions.

Thus, black areas of the hair coat are prone to absorb more radiant energy and become hotter than the white ones. Dark coats have been considered to acquire greater heat load from solar radiation than those with light-coloured coats (Finch et al., 1984) and therefore white cows have been predominantly assumed as the most desirable ones for tropical environments (Goodwin et al., 1995, 1997). However, Holstein cows always present non-pigmented skin under their white coats. It has been experimentally demonstrated that short-wave radiation - including ultraviolet (UV) - is effectively transmitted through the white coats (Silva et al., 2003) and strikes a skin that is lacking any melanin protection. On the other hand, there is a highly pigmented skin under a black coat. The subsequent excess of heating (because the greater absorptance of black surfaces) is compensated by an increased heat loss by cutaneous evaporation.

Table 1 - Mean squares of skin temperature $\left(T_{\mathrm{s}}\right)$, sweating rate $(S)$ and heat loss by cutaneous evaporation $\left(E_{\mathrm{s}}\right)$ of Holstein cows

\begin{tabular}{lcccc}
\hline Source & d.f. & $T_{\mathrm{s}}$ & $S$ & $E_{\mathrm{s}}$ \\
\hline Cows & 15 & $31.40 * *$ & $55,008.0 * *$ & $24,840.2 * *$ \\
Colour & 1 & $14.372 \mathrm{~ns}$ & $32,857.2 \mathrm{~ns}$ & $15,070.3 \mathrm{~ns}$ \\
Residual & 313 & 6.25 & $13,684.9$ & $6,190.8$ \\
\hline \multicolumn{4}{l}{ ns = statistically non-significant; $* * \mathrm{P}<0.01$}
\end{tabular}

In a tropical region, predominantly black Holstein cows are likely to present higher average milk yield than those predominantly white even in latitudes as low as $5^{\circ}$, as it was observed by Morais et al. (2010). Because the very high short-wave irradiance of tropical regions, protection of the body of the animal against UV is far more important than that protection against body warming - which can be compensated by the increased evaporation of sweat. In fact, short-wave solar radiation and especially the UV are easily transmitted through the white coat of Holsteins and strike the subjacent non-pigmented skin, reaching the dermal tissues; on the other hand, the black coat has a lower transmittance and the highly pigmented skin always underneath it acts as an efficient barrier for solar shortwave radiation (Silva et al., 2003).

Taking into account the hypothesis that a rise in the skin temperature results in an increased sweating rate, it would be expected that $E_{\mathrm{s}}$ values were higher in the black than in the white coat areas. In fact, the black areas presented an average sweating rate $\left(138.9 \pm 8.5 \mathrm{~g} \cdot \mathrm{m}^{-2} \cdot \mathrm{h}^{-1}\right)$ significantly higher $(\mathrm{P}<0.05)$ than that of the white areas $\left(109.5 \pm 9.7 \mathrm{~g} \cdot \mathrm{m}^{-2} \cdot \mathrm{h}^{-1}\right)$ (Table 2$)$.

The difference between the mean $E_{\mathrm{s}}$ values of the black $\left(93.3 \pm 5.7 \mathrm{~W} . \mathrm{m}^{-2}\right)$ and the white $\left(73.6 \pm 6.5 \mathrm{~W} \cdot \mathrm{m}^{-2}\right)$ areas was also significant $(\mathrm{P}<0.05)$, as expected.

Gatenby (1986) determined for 3/4 Hereford-1/4 Zebu in Kenya that the sweating rate was exponentially related to $T_{\mathrm{S}}$ by the function

$S=0.004+0.001 e^{\left(T_{s}-33.8\right) / 0.94}, \quad$ g.m ${ }^{-2} \cdot s^{-1}$

In contrast, Finch et al. (1982) found that the rectal temperature was more important than $T_{\mathrm{s}}$ and the mean radiant temperature (as calculated from $T_{\mathrm{g}}$ ) for the evaporative response of Brahman, Shorthorn and crossbred cattle in Queensland, Australia.

In order to find a relationship between $E_{\mathrm{S}}$ and $T_{\mathrm{s}}$ based on the present study, several attempts were made and the equation that fitted the data better was:

$E_{s}=31.5+3.67 e^{\left(T_{s}-27.9\right) / 2.19115} \mathrm{~W} \cdot \mathrm{m}^{-2}$

whose coefficient of determination was $\mathrm{r}^{2}=0.68$ ( Figure 1 ).

The line for Gatenby's equation in Figure 1 was obtained by multiplying equation [4] by the latent heat of vaporization

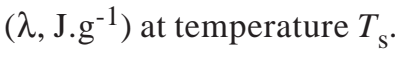

Table 2 - Means, standard errors (upper values) and range values (between parentheses) of three traits of Holstein cows

\begin{tabular}{lcc}
\hline Trait & White coat $(n=144)$ & Black coat $(n=188)$ \\
\hline Sweating rate $\left(\mathrm{g} . \mathrm{m}^{-2} \cdot \mathrm{h}^{-1}\right)$ & $109.5 \pm 9.7 \mathrm{a}(4.4-507.6)$ & $138.9 \pm 8.5 \mathrm{~b}(3.5-572.5)$ \\
Evaporative heat loss $\left(\mathrm{W} . \mathrm{m}^{-2}\right)$ & $73.6 \pm 6.5 \mathrm{c}(3.0-340.7)$ & $93.3 \pm 5.7 \mathrm{~d}(2.4-384.3)$ \\
Skin temperature $\left({ }^{\circ} \mathrm{C}\right)$ & $32.6 \pm 0.2 \mathrm{e}(25.8-38.1)$ & $33.2 \pm 0.2 \mathrm{f}(26.2-38.0)$ \\
\hline
\end{tabular}

Means with different letter in the same line differ statistically by Duncan's test $(\mathrm{P}<0.05)$. 


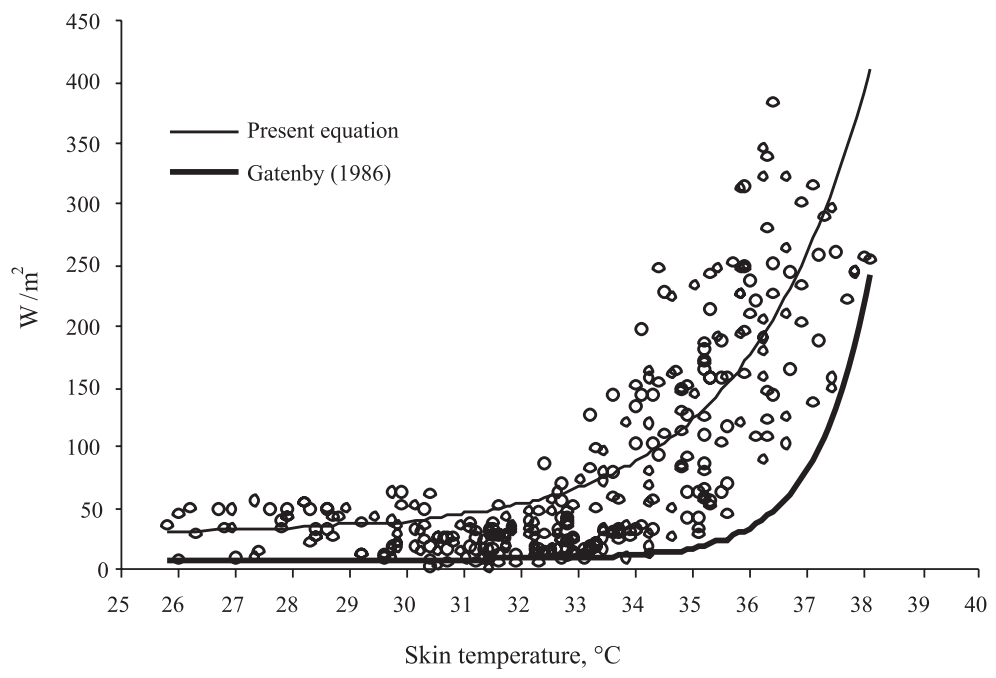

Figure 1 - Heat loss by cutaneous evaporation as function of the skin temperature $\left(T_{\mathrm{s}}\right)$ measured in Holstein cows bred in a tropical environment. Present equation is $E_{\mathrm{s}}=31.5+3.67 \exp \left\{\left(T_{\mathrm{s}}-27.9\right) / 2.19115\right\}$.

This figure shows that the effect of $T_{\mathrm{s}}$ on $E_{\mathrm{s}}$ begins at about $31^{\circ} \mathrm{C}$ and that before this threshold is reached, $E_{\mathrm{s}}$ remains almost constant $\left(48 \mathrm{~W} \cdot \mathrm{m}^{-2}\right.$ on the average and barely reaching $50 \mathrm{~W} \cdot \mathrm{m}^{-2}$ ). These last values probably reflect the evaporation resulting from the insensible perspiration; they are much higher than that $14.4 \mathrm{~W} . \mathrm{m}^{-2}$ that can be deduced from Gatenby's data. It is clear that by Gatenby's equation, the animals are expected to have $E_{\mathrm{s}}$ increased only after $T_{\mathrm{S}}$ has reached $34^{\circ} \mathrm{C}$, although this equation was designed for tropical cattle also. Indeed, the respective line does not fit the data of the present study.

The fact that Gatenby worked with crossbred beef cattle and based her study on 28 observations of five animals only would be an explanation for the difference. On the other hand, different populations of tropical cattle could have different thermoregulatory tactics, even within the same breed, because of the variations in their genetic characteristics. Perhaps, it would be advisable to use only prediction equations designed specifically for a given population.

Equation [5] can be used to estimate $E_{\mathrm{s}}$ when the number of animals to be measured is great, for example in genetic surveys. In such a case, $T_{\mathrm{s}}$ can be determined rapidly by means of a long-range type of infra-red radiometer gun provided with a laser sight.

\section{Conclusions}

Skin surface temperature is a good predictor of the cutaneous evaporative rate of Holstein cows in a tropical environment. Cutaneous evaporation rate is related exponentially to the skin temperature. In Holstein cows, the skin surface temperature of the black areas of the hair coat is significantly higher than that of the white areas in the same animals, when they are exposed to solar radiation. The effect of the skin temperature on the cutaneous evaporation rate is barely perceptible until it reaches about $31^{\circ} \mathrm{C}$. Before this temperature is reached, the cutaneous evaporation rate is constant, being about $48 \mathrm{~W} \cdot \mathrm{m}^{-2}$ on the average.

\section{References}

ALLEN, T.E. Responses of Zebu, Jersey and Zebu x Jersey crossbred heifers to rising temperature with particular reference to sweating. Australian Journal Agricultural Research, v.13, p.165-179, 1962.

ALLEN, T.E.; BENNETT, J.W.; DONEGAN, S.M. et al. Moisture, its accumulation and site of evaporation in the coats of sweating cattle. Journal of Agricultural Science, v.74, p.247-258, 1970.

AMAKIRI, S.F.; ONWUKA, S.K. Quantitative studies of sweating rate in some cattle breeds in a humid tropical environment. Animal Production, v.30, p.383-388, 1980.

FINCH, V.A.; BENNETT, I.L.; HOLMES, C.R. Coat color in cattle: effect of thermal balance, behaviour, and growth and relationship with coat type. Journal of Agricultural Science, v.102, p.141-147, 1984.

FINCH, V.A.; BENNETT, I.L.; HOLMES, C.R. Sweating response in cattle and its relation to rectal temperature, tolerance of sun and metabolic rate. Journal of Agricultural Science, v.99, p.479-487, 1982.

GATENBY, R.M. Evaporimeter measuring sweat rate of cattle outdoors. Journal of Thermal Biology, v.5, p.21-27, 1980.

GATENBY, R.M. Exponential relation between sweat rate and skin temperature in hot climates. Journal of Agricultural Science, v.106, p.175-183, 1986.

GEBREMEDHIN, K.; CRAMER, C.O., PORTER, W.P. Predictions and measurements of heat production and food and water requirements of Holstein calves in different environmens. Transactions of the ASAE, v.3, p.715-720, 1981.

GEBREMEDHIN, K.; WU, B. A model of evaporative cooling of wet skin surface and fur layer. Journal of Thermal Biology, v.26, p.537-545, 2001.

GEBREMEDHIN, K.; WU, B. Simulation of sensible and latent heat losses from wet-skin surface and fur layer. Journal of Thermal Biology, v.27, 291-297, 2002. 
GOODWIN, P.J.; GAUGHAN, J.; SKELE, P. et al. Coat color and alleviation of heat load in Holstein-Friesian cows. In: INTERNATIONAL LIVESTOCK ENVIRONMENT SYMPOSIUM, 5., 1997, St. Joseph. Proceedings.... St. Joseph: ASAE, 1997. p.923-927.

GOODWIN, P.J.; JOSEY, M.; COWAN, J.M. Coat color and its effect on production in Holstein-Friesians in Southeast Queensland. In: AUSTRALIAN ASSOCIATION OF ANIMAL BREEDING AND GENETICS CONFERENCE, 11., 1995, Sydney. Proceedings... Sydney: Australian Association of Animal Breeding and Genetics, 1995. p.295-298.

HARVEY, W.R. Least squares analysis of data with unequal subclass numbers.Beltsville: Agricultural Research Service/ U.S. Department of Agriculture, 1960. 157p. ( Publ. ARS 20-8).

ISABIRYE, J.K.; ROBERTSHAW, D. The sweat gland response to solar radiation in domestic animals. Biometeorology, v.5, p.67-70, 1972.

MAIA, A.S.C.; SILVA, R.G.; LOURENÇO, C.M.B. Sensible and latent heat loss from the body surface of Holstein cows in a tropical environment. International Journal of Biometeorology, v.50, p.17-22, 2005.

McLEAN, J.A. Measurement of cutaneous moisture vaporization from cattle by ventilated capsules. Journal of Physiology, v.167, p.417-426, 1963a.

McLEAN, J.A. The partition of insensible loss of body weight and heat from cattle under various climatic conditions. Journal of Physiology, v.167, p.427-477, 1963b.
MORAIS, D.A.E.F.; MAIA, A.S.C.; SILVA, R.G. et al. Variação anual de características morfológicas e da temperatura da superfície do pelame de vacas da raça Holandesa em ambiente semiárido. Revista Brasileira de Zootecnia, v.39, p.837-844, 2010.

PINHEIRO, M.G.; SILVA, R.G. Pelame e produção de vacas da raça Holandesa em ambiente tropical. Boletim de Indústria Animal, v.55, p.1-6, 1998.

PINHEIRO, M.G.; SILVA, R.G. Estação do ano e características do pelame de vacas da raça Holandesa. Boletim de Indústria Animal, v.57, p.99-103, 2000.

SCHLEGER, A.V.; BEAN, K.G. Factors determining sweating competence of cattle skin. Australian Journal of Biological Sciences, v.24, p.1291-1300, 1971.

SCHLEGER, A.V.; TURNER, H.G. Sweating rates of cattle in the field and their reaction to diurnal and seasonal changes. Australian Journal Agricultural Research, v.16, p.92-106, 1975.

SILVA, R.G.; ARANTES-NETO, J.G.; HOLTZ-FILHO, S.V. Genetic aspects of the variation of the sweating rate and coat characteristics of Jersey cattle. Brazilian Journal Genetics, v.11, p.335-347, 1988.

SILVA, R.G.; La SCALA JUNIOR, N.; TONHATI, H. Radiative properties of the skin and haircoat of cattle and other animals. Transactions of the ASAE, v.46, p.913-918, 2003.

SOKAL, R.R.; ROHLF, F.J. Biometry. 3.ed. New York: W.H. Freeman, 1995. 887p. 